\title{
Effects of Seedborne Potato Virus Y Infection in Two Potato Cultivars Expressing Mild Disease Symptoms
}

\author{
D. C. Hane, Research Agronomist, Department of Crop and Soil Science, and P. B. Hamm, Extension Plant Pa- \\ thologist, Department of Botany and Plant Pathology, Oregon State University, Hermiston Agricultural Research \\ and Extension Center, P.O. Box 105, Hermiston 97838
}

\begin{abstract}
Hane, D. C., and Hamm, P. B. 1999. Effects of seedborne potato virus Y infection in two potato cultivars expressing mild disease symptoms. Plant Dis. 83:43-45.

The effects of seedborne potato virus Y (PVY) in Shepody and Russet Norkotah, two new cultivars that express mild disease symptoms, were determined by comparing tuber yield and specific gravity of plants grown from PVY-infected seed with those of adjoining plants grown from virus-free seed. Seedborne PVY-infected Shepody plants produced $28.7 \%$ less total yield in 1994, and 41.1 and $47.3 \%$ less in two trials in 1995. Marketable yield was reduced 55.8 and 79.4\% in 1995 trials. PVY infection did not affect specific gravity in Shepody. Seedborne PVY infections in Russet Norkotah reduced total yield by 45.5 and $48.8 \%$ in the 1994 and 1995 trials, respectively. During the 1995 trial, marketable yield from seedborne infected plants was reduced $65.1 \%$ compared with adjacent plants grown from noninfected seed. Additionally, specific gravity was lower for tubers from seedborne infected Russet Norkotah plants than from plants grown from noninfected seed in 1994. Seedborne infected plants of both varieties had fewer and smaller tubers than did plants grown from virus-free seed. No compensatory yield increase was measured for plants originating from PVY-free seed and growing adjacent to seedborne infected plants for either variety. Rather, yield reduction was observed in Russet Norkotah plants growing adjacent to seed infected plants in 1995. Enzyme-linked immunosorbent assay (ELISA) on Shepody in 1995 showed most plants grown from PVY-free seed became infected within 6 weeks of emergence.
\end{abstract}

Seedborne potato viruses are a chronic problem for commercial growers whether they are growing potatoes for seed, processing, or fresh market. The introduction of cultivars that express milder symptoms to potato virus Y (PVY) infections than Russet Burbank has led to an assumption that the effects on yield are not significant. Two new cultivars, Shepody and Russet Norkotah, express symptoms from seedborne PVY infection that are variable, but often show only a mild mosaic. Seedborne infections can also cause some stunting in Russet Norkotah, but this symptom is often absent in Shepody. Current season PVY infection often is undetectable by symptom expression alone and often results in high levels of PVY infection in seed because of the difficulty seed growers have in identifying and roguing infected plants.

Although the overall impact of PVY on potato production in the United States is not well documented, there is evidence that varietal differences exist $(1,5)$. Information

Corresponding author: D. C. Hane

E-mail: Dan.Hane@orst.edu

Oregon State University Agricultural Experiment Station Technical Paper 11389.

Accepted for publication 24 September 1998.

Publication no. D-1998-1023-03R

(C) 1999 The American Phytopathological Society is unavailable on the effects of PVY infection in either Shepody or Russet Norkotah. Compensatory yield increases have been reported for healthy plants growing adjacent to plants infected by potato leafroll virus $(2,3)$, but results on compensatory yields with PVY infection are mixed $(1,5,7)$.

The work reported here was undertaken to better understand the impact of PVY in Shepody and Russet Norkotah, where mild symptoms are often observed. Experiments were conducted to (i) compare tuber yield and quality between plants with seedborne PVY infection and plants from noninfected seed pieces, and (ii) determine the benefit, if any, of compensatory yield for plants grown from virus-free seed being adjacent to plants infected from seed piece inoculum.

\section{MATERIALS AND METHODS}

These experiments were conducted in 1994 and 1995 under center pivot irrigation in the Columbia Basin of Oregon, a low elevation $(<450 \mathrm{~m})$ desert environment with a growing season of 180 or more days.

In 1994, commercial fields of cultivars Shepody and Russet Norkotah potatoes were scouted on 1 June for the occurrence of seedborne PVY-infected plants. The Russet Norkotah field had been planted with seed rejected for certification (PVY virus levels exceeded the $3 \%$ allowed).
Planting dates were 22 and 23 March, and emergence for both varieties occurred about 1 May. Plants in both fields were approximately $30 \mathrm{~cm}$ tall at the time of selection. PVY-infected plants were selected only where symptom expression occurred throughout the plant and when bordered by at least three symptomless plants at both ends within the row and in the parallel bordering rows. Leaf samples were taken from the infected plant and an adjacent symptomless plant and then tested by enzyme-linked immunosorbent assay (ELISA). Comparisons were made only where a PVY-infected plant was adjacent to a virus-free plant, as established by ELISA. Eighteen comparisons were made for both cultivars. In-row spacing of plants was approximately $25.4 \mathrm{~cm}$. Rows were spaced at $0.86 \mathrm{~m}$. The Norkotah field was vine killed 7 July, while the Shepody vines remained green until harvest. The seedborne infected plant (plant 1), the adjacent plant grown from virus-free seed (plant 2), and the third plant in sequence, also grown from virus-free seed, (plant 3) were individually hand harvested on 21 July. Total tuber weight, tuber number, and specific gravity (air/water weight) were measured for each hill.

Similar comparisons were conducted in 1995. Two experiments, differentiated by seed source, were conducted for Shepody; one was conducted for Russet Norkotah. Seed for the Shepody experiments originated from the 1994 experiment (designated trial-A) and from seed certification samples grown in 1994 at the Hermiston Agricultural Research and Extension Center (designated trial-B). Seed for the Russet Norkotah trial also came from the 1994 trial. For all trials, only tubers of plants originating from virus-free seed in 1994 were used for seed in 1995 trials. This provided both a uniform seed source and limited PVY infections in seed to the previous season. To determine seed tuber virus status, all tubers were pretested by growing single buds of individual tubers in the greenhouse and assaying for PVY using ELISA.

On 17 April, field plots were established by planting five rows each of certified Shepody and Russet Norkotah seed. Plant spacing was $23.5 \mathrm{~cm}$ within rows, with rows spaced at $0.86 \mathrm{~m}$. Individual plots consisting of one virus-infected seed piece (plant 1) followed by two virus-free seed 
Table 1. Effect of seedborne potato virus Y (PVY) infection on yield, tuber numbers, average tuber size, and specific gravity in Shepody potatoes

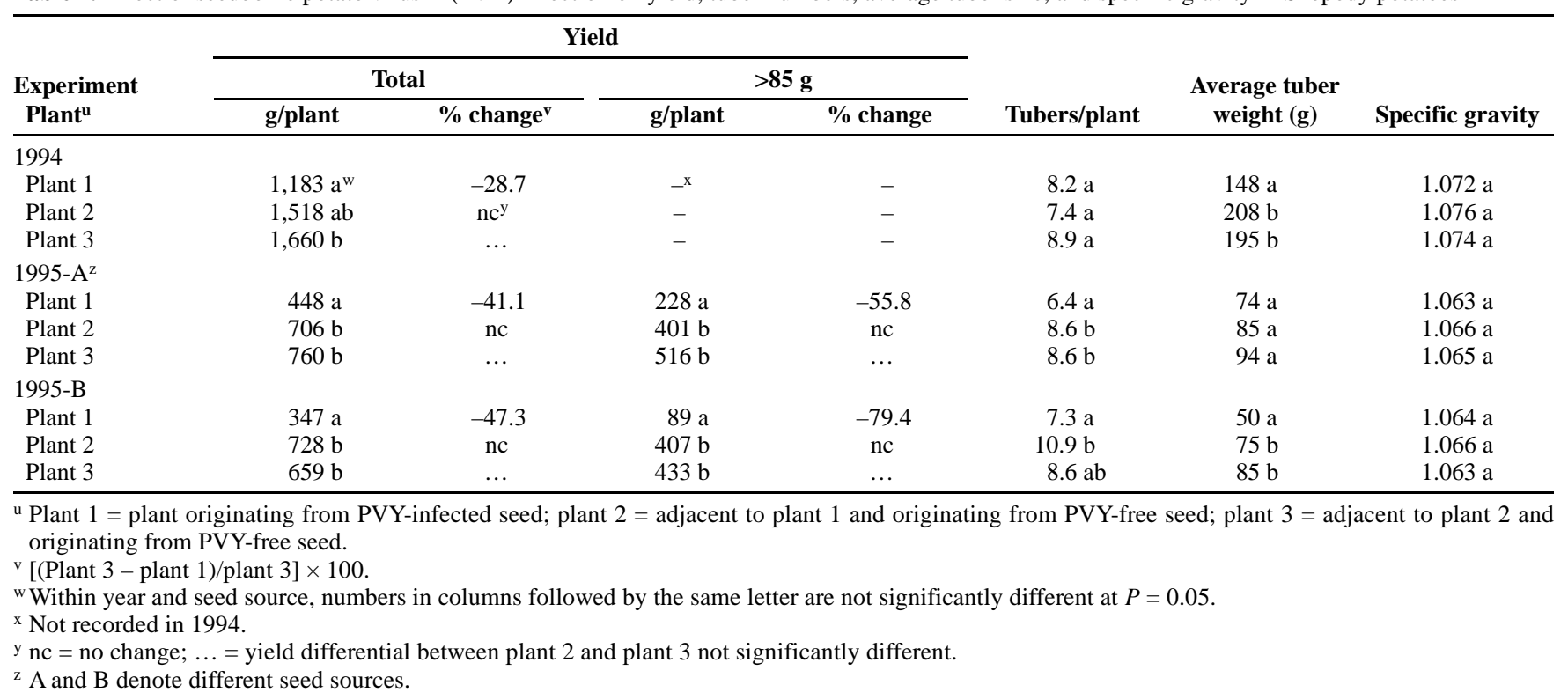

Table 2. Effect of seedborne potato virus Y (PVY) infection on yield, tuber numbers, average tuber size, and specific gravity in Russet Norkotah potatoes

\begin{tabular}{|c|c|c|c|c|c|c|c|}
\hline \multirow{3}{*}{$\begin{array}{l}\text { Experiment } \\
\text { Plant }^{v} \\
\end{array}$} & \multicolumn{4}{|c|}{ Yield } & \multirow[b]{3}{*}{ Tubers/plant } & \multirow{3}{*}{$\begin{array}{l}\text { Average tuber } \\
\text { weight (g) }\end{array}$} & \multirow[b]{3}{*}{ Specific gravity } \\
\hline & \multicolumn{2}{|c|}{ Total } & \multicolumn{2}{|c|}{$>85 \mathrm{~g}$} & & & \\
\hline & g/plant & $\%$ change $^{w}$ & g/plant & \% change & & & \\
\hline \multicolumn{8}{|l|}{1994} \\
\hline Plant 1 & $1,057 \mathrm{a}^{\mathrm{x}}$ & -45.5 & $-\mathrm{y}$ & - & $8.2 \mathrm{a}$ & $129 \mathrm{a}$ & $1.070 \mathrm{a}$ \\
\hline Plant 2 & $1,647 \mathrm{~b}$ & $\mathrm{nc}^{\mathrm{z}}$ & - & - & $9.7 \mathrm{a}$ & $187 \mathrm{~b}$ & $1.077 \mathrm{~b}$ \\
\hline Plant 3 & $1,941 \mathrm{~b}$ & $\ldots$ & - & - & $11.6 \mathrm{a}$ & $185 \mathrm{~b}$ & $1.076 \mathrm{~b}$ \\
\hline \multicolumn{8}{|l|}{1995} \\
\hline Plant 1 & $438 \mathrm{a}$ & -48.8 & $187 \mathrm{a}$ & -65.1 & $6.1 \mathrm{a}$ & $73 a$ & $1.067 \mathrm{a}$ \\
\hline Plant 2 & $672 b$ & -21.4 & $312 \mathrm{a}$ & -41.8 & $10.1 \mathrm{~b}$ & $73 a$ & $1.070 \mathrm{a}$ \\
\hline Plant 3 & $855 \mathrm{c}$ & $\ldots$ & $536 \mathrm{~b}$ & $\ldots$ & $10.5 \mathrm{~b}$ & $91 \mathrm{a}$ & $1.070 \mathrm{a}$ \\
\hline
\end{tabular}

v Plant 1 = plant originating from PVY-infected seed; plant $2=$ adjacent to plant 1 and originating from PVY-free seed; plant $3=$ adjacent to plant 2 and originating from PVY-free seed.

${ }^{\mathrm{w}}[($ Plant 3 - plant 1)/plant 3] $\times 100$.

x Within year, numbers in columns followed by the same letter are not significantly different at $P=0.05$.

${ }^{y}$ Not recorded in 1994

${ }^{\mathrm{z}} \mathrm{nc}=$ no change; $\ldots=$ yield differential between plant 2 and plant 3 not significantly different.

pieces (plant 2 and plant 3) were established by replacing certified seed pieces with either virus-infected or virus-free seed pieces as determined from greenhouse tests. Each plot was completely separated in the row and between rows by plants grown from certified seed. Plots were managed using cultural practices recommended for this area.

Plants in all plots were ELISA tested shortly after $100 \%$ emergence (24 May) to verify their virus status. Shepody trial-A, Shepody trial-B, and the Norkotah trial had 16,16 , and 13 replications, respectively. All healthy Shepody plants were again ELISA tested on 20 June to determine spread of current season infection into adjacent plants.

A severe hail storm on 9 July shortened the growing season by approximately 2 weeks, but regrowth was sufficient in Shepody to allow a final ELISA for all plants. All surviving growth in all experiments was arrested on 19 July with an application of monocarbamide dihydrogensulfate at
187 liters $\mathrm{ha}^{-1}$ diluted 1:1 with water for 374 liters $\mathrm{ha}^{-1}$, and the plants were harvested on 9 August. Data for each hill were gathered as previously described. In addition, marketable yield determinations were made by obtaining total weight of tubers weighing more than $85 \mathrm{~g}$.

Differences between plants grown from infected seed pieces and those grown from noninfected seed pieces were tested using a randomized complete block analysis of variance and a 5\% level of significance for separation of means (6). Mauchly's test of sphericity (4) was used to check the validity of the model since treatments were observations in a repeated measures sequence (distance cannot be randomized). There was no indication of nonsphericity, and the model was accepted.

\section{RESULTS}

Shepody plants grown from PVY-infected seed produced a smaller total yield than plants grown from virus-free seed
(Table 1). Total yield was reduced by 28.7 , 41.1 , and $47.3 \%$ in plants grown from PVY-infected seed (Table 1, plant 1) when compared with those grown from virusfree seed (plant 3) for 1994, 1995-A, and 1995-B trials, respectively. Likewise, seedborne infected Russet Norkotah plants produced a smaller total yield by 45.5 and $48.8 \%$ in 1994 and 1995, respectively, than plants grown from PVYfree seed (Table 2). Total yield of Shepody plants (plant 2) growing adjacent to seedborne infected plants did not differ from that of plant 3 (Table 1). In Russet Norkotah, a decrease in yield was measured for plant 2 when compared with plant 3 in 1995, both in total and marketable yields (Table 2).

Marketable yield of tubers from Shepody plants (tubers weighing more than 85 g) was measured in 1995. When compared with plant 3 , which originated from virusfree seed, the seedborne infected plant (plant 1) produced 55.8 and $79.4 \%$ less marketable yield for experiments 1995-A 
and 1995-B, respectively (Table 1). In the 1995 Russet Norkotah trial, reduction in percent marketable yield for seedborne infected plants was $65.1 \%$ when compared with plant 3 (Table 2).

In the 1995-A trial, infected Shepody plants produced fewer tubers than either adjacent plant 2 or plant 3 (Table 1). Similarly, in 1995, seedborne infected Russet Norkotah plants produced fewer tubers than plants grown from virus-free seed (Table 2). Average tuber weight was also reduced in both cultivars for plants grown from seedborne infection. Average tuber weight in Shepody was reduced from 195 to $148 \mathrm{~g}$ in 1994 , a loss of $24.1 \%$. In 1995, Shepody tuber size was reduced $41.2 \%$, going from 85 to $50 \mathrm{~g}$. In Russet Norkotah, a $30.3 \%$ reduction in average tuber weight was measured in 1994, falling from 185 to $129 \mathrm{~g}$.

Specific gravity in Shepody was unaffected by seedborne infections, whereas in Russet Norkotah, specific gravity of tubers was lower for seedborne infected plants only in 1994 (Tables 1 and 2).

Most Shepody plants grown from PVYfree seed (plants 2 and 3) became infected as the growing season progressed (Table 3 ). One month after the first assay, $90.6 \%$ of plants 2 and $84.4 \%$ of plants 3 were found to be infected. By mid-July, nearly all plants were infected.

\section{DISCUSSION}

These results show that degree of symptom expression is not a reliable indicator of the effects of seedborne PVY infection on tuber yield and quality. The two cultivars, Shepody and Russet Norkotah, both of which express mild symptoms to PVY infection, were found to be significantly impacted by this virus. With Shepody, reductions in marketable yield for seedborne infected plants were 15 and 30\% greater than losses measured for total yield (Table 1, 1995-A and 1995-B). In Russet Norkotah, reduction in marketable yield was also greater than reduction in total yield, 65.1 verses $48.8 \%$. Gladders and Campbell-Hill (1) also reported a higher percent yield loss for marketable tubers than for total yield with infected plants. However, their data show only about a $4 \%$ differential for the cultivar Morene compared with $15 \%$ or more found in the varieties tested here.

The number of tubers per plant for these cultivars was sometimes reduced in plants infected with seedborne PVY. This agrees with other work involving seedborne infections of PVY $(1,5)$.
The reduction in average tuber weight for both Shepody and Russet Norkotah coupled with fewer tubers per plant accounts for the greater reduction measured for marketable yield than for total yield. The lack of disparity between treatments for tuber weight for Russet Norkotah in 1995 could be associated with the hailshortened season, which prevented full development of plants grown from virusfree seed.

No difference was observed in specific gravity for Shepody between tubers of plants grown from infected seed and those grown from noninfected seed, but specific gravity was reduced in Russet Norkotah in 1994. It is unlikely that maximum specific gravity was attained in 1995 due to interruption of growth by a hail storm. However, since Russet Norkotah is not used for processing, a reduced specific gravity is not considered important.

The large differential in yield between years was attributed to the hail-shortened season in 1995. The shortened season may also relate to the higher percent reductions in total yield seen in 1995. The yield losses measured in this work were comparable to those reported for other cultivars $(1,5,7)$, but losses in all studies have been variable, and the uniqueness due to virus, variety, and environment should always be considered.

Total yield of Shepody plants developing from virus-free seed (plant 2) and growing adjacent to seedborne infected plants was never higher than that of its neighbor (plant 3), indicating no compensatory effect due to plant 2 being adjacent to the less competitive seedborne infected plant (Table 1). Likewise, no compensatory yield effects were measured for Russet Norkotah. Rather, in the 1995 experiment, the plant with a potential compensatory advantage (plant 2) yielded less than the plant adjacent to it (plant 3), which had no positional advantage. It is likely that plant 2 became infected early enough in the season to negatively impact its yield. These results agree with those of Gladders and CampbellHill (1), who found no compensatory increases in yield for the cultivar Morene from a healthy plant growing adjacent to a single plant with seedborne PVY infection.

In 1995, ELISA confirmed that most Shepody plants grown from virus-free seed became PVY infected within 65 days of planting when adjacent to seedborne infected plants (Table 2). This would be 35 to 40 days after plant emergence. This rate of PVY spread to adjacent plants that were grown from virus-free seed likely occurred
Table 3. Number and percentage of Shepody plants positive for PVY by enzyme-linked immunosorbent assay (ELISA) testing at three dates, Hermiston, Oregon, 1995

\begin{tabular}{llll}
\hline & \multicolumn{3}{c}{ No. $(\%)$ positive plants } \\
\cline { 2 - 4 } Test date & Plant 1 & Plant 2 & Plant 3 \\
\hline $5 / 24$ & $32(100)$ & $0(0)$ & $0(0)$ \\
$6 / 20$ & $-{ }^{z}$ & $29(90.6)$ & $27(84.4)$ \\
$7 / 18$ & - & $31(96.9)$ & $28(87.5)$ \\
\hline
\end{tabular}

y Plant 1 = originating from PVY-infected seed; plant $2=$ adjacent to plant 1 and originating from PVY-free seed; plant $3=$ adjacent to plant 2 and originating from PVY-free seed.

z Not retested, all were PVY positive on 5/24

in 1994 as well. Additionally, Russet Norkotah was affected more by currentseason PVY infection than was Shepody, as indicated by a yield reduction for plant 2 compared with plant 3 in 1995 only for Russet Norkotah.

Due to the yield and quality losses associated with seedborne PVY infections reported here, and because of the apparent ease with which PVY can spread, at least in this environment, and the subsequent difficulties in identifying infection in these cultivars, seed growers need to increase their efforts to plant only virus-free seed and rogue infected plants. Clearly, commercial production can also benefit by planting seed lots with low amounts of PVY and controlling current-season spread of infection.

\section{ACKNOWLEDGMENTS}

This research was supported by the Oregon Potato Commission. We thank Joy Jaeger for technical assistance. We thank Pete Thomas for supplying antisera and Dennis Johnson and Ken Johnson for critically reviewing the manuscript.

\section{LITERATURE CITED}

1. Gladders, P., and Campbell-Hill, C. E. 1988. Effect of potato virus $\mathrm{Y}$ on the yield of potato cultivar Morene. Tests Agric. Chem. Cultivars 9:90-91.

2. Harper, F. R., Nelson, G. A., and Pittman, U. J. 1975. Relationship between leaf roll symptoms and yield in Netted Gem potato. Phytopathology 65:1242-1244.

3. Kirkpatrick, H. C., and Blodgett, F. M. 1943. Yield losses caused by leaf roll of potatoes. Am. Potato J. 20:53-56.

4. Kuel, R. O. 1994. Statistical Principles of Research Design and Analysis. Chapter 15. Duxbury Press, Belmont, CA.

5. Kurppa, A., and Hassi, A. 1989. Reaction of four table potato cultivars to primary and secondary infection by potato virus $\mathrm{Y}^{\mathrm{O}}$ and $\mathrm{Y}^{\mathrm{N}}$. Ann. Agric. Fenn. 28:297-307.

6. SAS Institute. 1988. SAS/STAT User's Guide. Rel. 6.03 ed. SAS Institute, Cary, NC.

7. Wooster, P. 1988. Tolerance to potato virus $\mathrm{Y}^{\mathrm{O}}$ Pages 103-107 in: Aspects of Applied Biology, Parts 1 and 2. 